\title{
Alternative RNA Splicing of the NMDA Receptor NR1 mRNA in the Neurons of the Teleost Electrosensory System
}

\author{
Daniele Bottai, ${ }^{1}$ Leonard Maler, ${ }^{2}$ and Robert J. Dunn ${ }^{1,3,4}$ \\ ${ }^{1}$ Center for Research in Neuroscience, Montréal General Hospital Research Institute, Montréal, Québec, Canada H3G \\ 1A4, ${ }^{2}$ Department of Anatomy and Neurobiology, University of Ottawa, Ottawa, Ontario, Canada K1H 8M5, and \\ Departments of Biology and ${ }^{4}$ Neurology, McGill University, Montréal, Québec, Canada H3G 1 A4
}

\begin{abstract}
The sequence for cDNA encoding the NMDA receptor subunit 1 (aptNR1) of the weakly electric fish Apteronotus leptorhynchus has been determined. The deduced amino acid sequence is $\sim 88 \%$ identical to other vertebrate NR1 proteins, with sequence homology extending to the alternatively spliced cassettes $\mathrm{N} 1$ and $\mathrm{C} 1$. The fish and mammalian $\mathrm{N} 1$ and $\mathrm{C} 1$ splice cassettes are identical at 20 of 21 and 30 of 37 amino acid positions, respectively. We did not detect a $\mathrm{C} 2$ splice cassette in aptNR1 mRNA, but we did find two novel C-terminal alternative splice cassettes labeled $\mathrm{C}^{\prime}$ ' and $\mathrm{C} 1^{\prime \prime}$.

The relative levels of NR1 transcripts containing the $\mathrm{N} 1$ and C1 splice cassettes were determined by using RNase protec-
\end{abstract}

tion and in situ hybridization analysis. N1-containing mRNAs are more abundant in caudal brain regions, similar to the patterns reported for mammalian brain. In contrast, the relative levels of transcripts containing the $\mathrm{C} 1$ splice cassette are much lower in fish than in mammals, averaging only $9 \%$ for the whole brain. The levels of $\mathrm{C} 1$ splicing increased in more rostral brain regions. In situ hybridizations with $\mathrm{N} 1$ - and $\mathrm{C} 1$-specific probes demonstrated that $\mathrm{N} 1$ cassette splicing occurs in most neurons but that $\mathrm{C} 1$ splicing is heterogeneous and is restricted to a subset of neuronal types in the electrosensory system.

Key words: NMDA receptor; electrosensory system; NR1 subunit; RNA splicing; evolution; fish neurons
Glutamate is the principal excitatory transmitter in the vertebrate brain. The receptors for glutamate are classified broadly into families of ionotropic and metabotropic receptors, the ionotropic receptors subclassified as either AMPA/kainate or NMDA types. The NMDA types are distributed throughout the CNS and display a unique combination of voltage sensitivity and calcium ion permeability that is important for neuronal differentiation, synaptic plasticity, and neurotoxicity.

In mammals the NMDA receptor is an oligomeric protein complex containing the obligatory NR1 subunit and one or more of the four NR2 subunits (Hollmann and Heinemann, 1994). Gene expression from the single NR1 gene generates nine different NR1 receptor subunit proteins via the use of alternative RNA splice cassettes (Zukin and Bennett, 1995). In contrast, each of the NR2 subunits NR2A/2B/2C/2D is encoded by a different gene. (Ikeda et al., 1992; Kutsuwada et al., 1992; Meguro et al., 1992; Monyer et al., 1992; Ishii et al., 1993). The voltage dependencies and kinetics of receptor responses depend on which of the NR1 splice variants and NR2 subunits are assembled into the receptor complex. Mapping of the NMDA receptor subunits in rat brain has revealed a complex mosaic of the NR1 splice variants and NR2 subunits that is believed to tailor synaptic responses to the requirements of different neural networks (Ishii et al., 1993; Buller et al., 1994; Laurie and Seeburg, 1994; Monyer

\footnotetext{
Received March 5, 1998; revised April 23, 1998; accepted April 30, 1998.

This work was supported by grants to R.J.D. and L.M. from the Medical Research Council of Canada. We thank William Ellis for technical support and Dr. Peter Seeburg for the rat NR1 cDNA.

Correspondence should be addressed to Dr. Robert Dunn, Center for Research in Neuroscience, Montréal General Hospital Research Institute, 1650 Cedar Avenue, Montréal, Québec, Canada H3G 1A4.

Dr. Bottai's present address: Max Planck Institute for Medical Research, Heidelberg, Germany 69120.

Copyright (C) 1998 Society for Neuroscience $\quad 0270-6474 / 98 / 185191-12 \$ 05.00 / 0$
}

et al., 1994; Petralia et al., 1994; Standaert et al., 1994, 1996; Landwehrmeyer et al., 1995; Laurie et al., 1995; Dunah et al., 1996; Johnson et al., 1996; Paupard et al., 1997).

NR1 subunits have been characterized by molecular cloning from rat (Moriyoshi et al., 1991), mouse (Yamazaki et al., 1992), human (Planells-Cases et al., 1993), duck (Kurosawa et al., 1994), and Xenopus (Soloviev et al., 1996). The rat NR1 gene contains 22 exons, four of which (exons 3, 5, 21, and 22) undergo alternative RNA splicing to generate nine splice variants (Anantharam et al., 1992; Sugihara et al., 1992; Durand et al., 1993; Hollmann et al., 1993). Splice insertion of the cassette N1 (exon 5) in the $\mathrm{N}$-terminal region of NR1 yields NMDA receptors with reduced agonist affinity, increased current amplitudes, decreased sensitivity to proton inhibition, altered responses to activated PKC, and a failure to respond to $\mathrm{Zn}^{2+}$ and polyamines (Durand et al., 1993; Hollmann et al., 1993; Zhang et al., 1994; Zheng et al., 1994; Paoletti et al., 1995; Traynelis et al., 1995). The C1 cassette (exon 21) contains major regulatory sites phosphorylated by protein kinases A and C (Tingley et al., 1993, 1997; Leonard and Hell, 1997) and the high-affinity calmodulin binding site (Ehlers et al., 1996). Phosphorylation of the receptor potentiates the NMDA currents, possibly via an inhibition of calmodulin binding to the C1 segment (Tingley et al., 1993, 1997; Tong et al., 1995; Ehlers et al., 1996; Hisatsune et al., 1997). C1 also may play a role in the subcellular targeting of NMDA receptors (Ehlers et al., 1995). Thus alternative splicing at the C-terminal segment of subunit NR1 can affect both subcellular localization and modulation of the NMDA receptor.

We are studying the molecular mechanisms that are critical for the extraction of specific sensory features by the neurons of the electrosensory system of the electric fish Apteronotus leptorhynchus. NMDA receptor-mediated neurotransmission is central to this process, as it is for the mammalian sensory systems (Bastian, 
1993, 1995; Daw et al., 1993; Collingridge and Bliss, 1995). A critical question concerns the extent to which the features of NMDA receptor structure and regulation have been conserved since the divergence $(\approx 400$ million years ago) of teleosts such as Apteronotus from the vertebrate lineage leading to mammals. In a previous study we have shown that an mRNA encoding the NR1 subunit is distributed broadly in the Apteronotus CNS and is expressed by many neurons of the electrosensory system (Bottai et al., 1997). We now have determined the full structure of the fish NR1 protein, including the sequences of the alternatively spliced cassettes. The patterns of alternative RNA splicing of aptNR1 in the fish CNS provide evidence for neuron-specific control of NR1 splice cassette selection and for evolutionary conservation of the regulation of this process.

\section{MATERIALS AND METHODS}

\section{$R N A$ isolation}

Tissue samples were dissected from A. leptorhynchus liver, brain, and subregions of the brain, including electrosensory lateral line lobe (ELL), cerebellum, forebrain, brainstem, midbrain (optic tectum plus torus semicircularis), and hypothalamus. Tissues were frozen in liquid nitrogen immediately after dissection, and RNA was prepared by extraction with TRIzol reagent (Life Technologies, Gaithersburg, MD), as described by Chomczynski and Sacchi (1987). The RNA concentration was estimated from UV absorbance at 260 and $280 \mathrm{~nm}$.

\section{Isolation of $c D N A s$}

A. leptorhynchus brain cDNA libraries were constructed in $\lambda \mathrm{Z}$ ap II and HybriZap (Stratagene, La Jolla, CA). These libraries were probed with the rat NMDAR1 cDNA nucleotides (nt) -269 to 3500 (Moriyoshi et al., 1991) and the 768 bp partial aptNR1 cDNA previously reported [nt 158-915 (Bottai et al., 1997)]. Hybridization-positive phages were purified, and the cDNA inserts were analyzed by DNA sequence analysis.

The central region of the AptNR1 cDNA (nt 1576-2543) was recovered by PCR amplification from cDNA prepared from A. leptorhynchus brain mRNA. The cDNA was prepared with the reagents supplied in the Superscript Preamplification System (Life Technologies). Fish brain mRNA $(1 \mu \mathrm{g})$ was annealed with $150 \mathrm{ng}$ of random hexamers in an $11 \mu \mathrm{l}$ reaction. After being heated at $70^{\circ} \mathrm{C}$ for $10 \mathrm{~min}$, the reaction was chilled in ice for $1 \mathrm{~min}$ and then diluted to a final volume of $20 \mu \mathrm{l}$ containing (in mM) 20 Tris- $\mathrm{HCl}, \mathrm{pH} 8.4,50 \mathrm{KCl}, 2.5 \mathrm{MgCl}_{2}$, and $2.5 \mathrm{dNTPs}$ plus 0.01 $\mathrm{M}$ dithiothreitol (DTT). After $5 \mathrm{~min}$ at $25^{\circ} \mathrm{C}, 200 \mathrm{U}$ of Superscript II RT were added, and the solution was incubated for $10 \mathrm{~min}$ at $25^{\circ} \mathrm{C}$ and for 50 $\min$ at $42^{\circ} \mathrm{C}$. The enzyme was heat-inactivated at $70^{\circ} \mathrm{C}$ for $15 \mathrm{~min}$, the reaction was chilled on ice, and $2 \mathrm{U}$ of RNase $\mathrm{H}$ were added and then incubated at $37^{\circ} \mathrm{C}$ for $20 \mathrm{~min}$. The PCR step was performed in (in mM) 20 Tris- $\mathrm{HCl}$, pH 8.4, $50 \mathrm{KCl}$, and $1.5 \mathrm{MgCl}_{2}$ plus $200 \mu \mathrm{M}$ dNTPs, a $5 \mu \mathrm{M}$ concentration of the two primers Rob 1 and 2, and $1.25 \mathrm{U}$ of Tsg DNA polymerase (Sangon, Canada). The cycle conditions included one cycle at $94^{\circ} \mathrm{C} / 2 \mathrm{~min}$ and 30 cycles at $94^{\circ} \mathrm{C} / 1 \mathrm{~min}, 56^{\circ} \mathrm{C} / 1.5 \mathrm{~min}$, and $72^{\circ} \mathrm{C} / 2.5$ min, with a final extension at $72^{\circ} \mathrm{C} / 10 \mathrm{~min}$. The products were analyzed by agarose gel electrophoresis, gel-purified, and subcloned in pGemT vector (Promega, Madison, WI).

The $5^{\prime}$ terminus of the cDNA was recovered by using the $5^{\prime}$ race system for rapid amplification of cDNA ends (RACE), version 2.0 (Life Technologies $)$. Primer Dano $26(2.5 \mathrm{pmol})$ was mixed with $1 \mu \mathrm{g}$ of brain mRNA in a $14 \mu \mathrm{l} \mathrm{vol} \mathrm{of} \mathrm{H}_{2} \mathrm{O}$. The mixture was denatured for $10 \mathrm{~min}$ at $70^{\circ} \mathrm{C}$ and chilled in ice. cDNA synthesis was performed in $20 \mu \mathrm{l}$ of (in mM) 20 Tris- $\mathrm{HCl}, \mathrm{pH} 8.4,50 \mathrm{KCl}, 2.5 \mathrm{MgCl}_{2}$, and 0.4 each dNTPs plus $0.01 \mathrm{M} \mathrm{DTT}$, and $200 \mathrm{U}$ Superscript II RT at $42^{\circ} \mathrm{C}$ for $50 \mathrm{~min}$. The enzyme was heat-inactivated at $70^{\circ} \mathrm{C}$ for $15 \mathrm{~min}$ and chilled in ice; then RNase $\mathrm{H}(2 \mathrm{U})$ was added and incubated at $37^{\circ} \mathrm{C}$ for $30 \mathrm{~min}$. The cDNA was purified through a Glass Max DNA isolation spin cartridge and recovered in $50 \mu$ l of $\mathrm{H}_{2} \mathrm{O}$.

The $5^{\prime}$ tailing reaction was performed by incubation $\left(37^{\circ} \mathrm{C} / 10 \mathrm{~min}\right)$ of $10 \mu \mathrm{l}$ of the purified cDNA product in PCR buffer [(in mM) 10 Tris-HCl, $\mathrm{pH} 8.4,25 \mathrm{KCl}$, and $1.5 \mathrm{MgCl}_{2}$ ] containing $20 \mu \mathrm{M} \mathrm{dCTP}$ and $1 \mu \mathrm{l}$ of terminal transferase in a final volume of $25 \mu$ l. The reaction mixture was heat-inactivated at $65^{\circ} \mathrm{C}$ for $10 \mathrm{~min}$ and chilled on ice. The $5^{\prime} \mathrm{RACE}$ product was amplified from the tailed cDNA, using primers Dano 27 and Abridge Anchor Primer. The reaction contained (in mM) 20 Tris- $\mathrm{HCl}$,
$\mathrm{pH} 8.4,50 \mathrm{KCl}$, and $1.5 \mathrm{MgCl}_{2}$ plus $200 \mu \mathrm{M}$ each dNTPs, $400 \mathrm{~nm}$ primers, $1 / 10$ dilution of the cDNA, and $2.5 \mathrm{U}$ of Tsg polymerase. The cycle conditions included one cycle at $94^{\circ} \mathrm{C} / 2 \mathrm{~min}, 35$ cycles at $94^{\circ} \mathrm{C} / 45 \mathrm{sec}$, $55^{\circ} \mathrm{C} / 1 \mathrm{~min}$, and $72^{\circ} \mathrm{C} / 1.5 \mathrm{~min}$, and the last cycle at $94^{\circ} \mathrm{C} / 45 \mathrm{sec}, 55^{\circ} \mathrm{C} / 1$ min, and $72^{\circ} \mathrm{C} / 7 \mathrm{~min}$. The single product was purified by agarose gel electrophoresis and cloned into vector pGemT (Promega).

\section{Isolation of alternatively spliced cDNAs}

$N 1$ cassette. Brain RNA was treated with DNase I $(50 \mu \mathrm{g} / \mathrm{ml})$ in $2 \mathrm{~mm}$ $\mathrm{MgCl}_{2}$ for $30 \mathrm{~min}$ at $4^{\circ} \mathrm{C}$. The reaction was stopped with $5 \mathrm{~mm}$ EDTA and then heat-inactivated at $65^{\circ} \mathrm{C}$ for $10 \mathrm{~min}$. cDNA synthesis $(0.2 \mu \mathrm{g}$ of RNA) was performed in $50 \mathrm{~mm} \mathrm{KCl,} 10 \mathrm{~mm}$ Tris-HCl, pH 9.0, $1 \%$ Triton X-100, 0.01 м DTT, $200 \mu \mathrm{M}$ dNTPs, $0.16 \mu \mathrm{M}$ primer Dano 9, $25 \mathrm{U}$ of RNasin, and $200 \mathrm{U}$ of Superscript II RT at $42^{\circ} \mathrm{C}$ for $1 \mathrm{hr}$. After heat inactivation $\left(95^{\circ} \mathrm{C} / 5 \mathrm{~min}\right)$, the cDNA was mixed in $50 \mathrm{~mm} \mathrm{KCl}, 10 \mathrm{~mm}$ Tris-HCl, pH 9.0, 0.1\% Triton X-100, $2 \mathrm{mM} \mathrm{MgCl}_{2}, 200 \mu \mathrm{M}$ dNTPs, $0.2 \mu \mathrm{M}$ primers Dano 8 and Dano 9 , and $2.5 \mathrm{U}$ of Taq DNA polymerase (Promega). The cycle conditions were one cycle at $94^{\circ} \mathrm{C} / 1 \mathrm{~min}, 40$ cycles of $92^{\circ} \mathrm{C} / 1 \mathrm{~min}, 55^{\circ} \mathrm{C} / 1.25 \mathrm{~min}$ and $72^{\circ} \mathrm{C} / 2.5 \mathrm{~min}$, with the last cycle of $92^{\circ} \mathrm{C} / 1 \mathrm{~min}, 55^{\circ} \mathrm{C} / 1.25 \mathrm{~min}$, and $72^{\circ} \mathrm{C} / 7 \mathrm{~min}$. The products were analyzed by agarose gel electrophoresis, gel-purified (Micropure separators, Amicon, Beverly, MA), and subcloned in pGemT.

$C$-terminal segments. cDNAs for the C-terminal RNA splice isoforms were isolated by PCR amplification, using primers on the $5^{\prime}$ (Dano 20) and $3^{\prime}$ (Dano 21, 22) sides of the junction region. The cDNA synthesis and PCR amplifications were performed as described above for the isolation of the central region. Dano 22 is located in the $\mathrm{C} 1$ cassette. The program PCR Primer (DNASTAR, Madison, WI) was used to design PCR primers.

\section{RNase protection assay}

Probes for RNase protection were prepared from cDNA segments inserted into the vector pGemT. The cDNA segments included (1) a $446 \mathrm{bp}$ Bam HI-Bam HI fragment (363-808) product containing the N1 cassette; (2) a 328 bp fragment (2765-3092) (primers 23 and 21) containing the $\mathrm{C} 1$ cassette; and (3) a 185 bp fragment (2667-2851) (primers 25 and 24) containing $\mathrm{C1}^{\prime}-\mathrm{Cl}^{\prime \prime}-\mathrm{C} 1$ cassettes. The ${ }^{32} \mathrm{P}$-labeled RNA probes were prepared by transcription with SP6 or T7 RNA polymerase (Promega), using the conditions recommended by the manufacturer. The RNA probes were purified by electrophoresis as described (Bottai et al., 1997). The hybridization solution contained $40 \mathrm{~mm}$ PIPES, pH 6.4, $0.4 \mathrm{M} \mathrm{NaCl}$, $1 \mathrm{~mm}$ EDTA, and $80 \%$ formamide. For each reaction $5 \mu \mathrm{g}$ of total RNA was combined with $10^{6} \mathrm{cpm}$ of labeled probe and hybridized overnight at $55^{\circ} \mathrm{C}$. Nonhybridized RNA was digested with RNase A $(40 \mu \mathrm{g} / \mathrm{ml})$ and RNase T1 $(2 \mu \mathrm{g} / \mathrm{ml})$ for $1 \mathrm{hr}$ at $37^{\circ} \mathrm{C}$. Samples were treated further with SDS $(0.04 \%)$ and proteinase $\mathrm{K}(90 \mu \mathrm{g} / \mathrm{ml})$ for $30 \mathrm{~min}$ at $37^{\circ} \mathrm{C}$. The protected RNA/RNA duplexes were denatured and separated by electrophoresis in a 5\% polyacrylamide/8 $\mathrm{M}$ urea gel. After drying, the gels were exposed to x-ray films (BioMax MR, Kodak, Rochester, NY) for $35-60 \mathrm{hr}$ with an intensifier screen at $-80^{\circ} \mathrm{C}$.

\section{Oligonucleotide primers}

The RT-PCR N1 cassette included Dano 9, tgtacacagcggcagcatcctctt; Dano 8, ctcacgeccaccccagtctccta; Dano 10, gggagaccaagaataaaaa; and Dano 11, tgccttgggtcctcgcttg. The RT-PCR for 3 'end splice isoforms included Dano 20, gctacaagcgccacaaagac; Dano 21, agagaagttcccgctggtagtt; Dano 22, ggccaccagcatcaagag; Dano 23, agagcagacccagaacc; Dano 24, ggatgacctacgtctcttg; and Dano 25, acaataaggaaagtgctgggagt. The Race PCR included Dano 26, acgtgcgcetggtgagc; Dano 27, cggtacgtaggaaggaaaggtggat; and Abridge Anchor, ggccacgcgtcgactagtacgggiigggiigggiig. The RT-PCR for the central domain included Rob1, ggagccgttcgtgtatgtga; and Rob2, gctggcetgtgatgtgtgtg.

\section{Northern blot}

RNA $(20 \mu \mathrm{g})$ from brain and liver was subjected to electrophoresis in a formaldehyde agarose gel (1\%). The RNA was blotted to nylon membrane (Hybond $\mathrm{N}^{+}$; Amersham Life Science, Arlington Heights, IL) and hybridized to $1.3 \mathrm{~kb}$ of fish NR1 cDNA at $42^{\circ} \mathrm{C}$ in $50 \%$ formamide, 40 $\mathrm{mm}$ phosphate buffer, $\mathrm{pH} 6.8,5 \times \mathrm{SSC}, 1 \% \mathrm{SDS}, 1 \%$ glycine, $5 \times$ Denhardt's, $100 \mu \mathrm{g} / \mathrm{ml}$ herring sperm DNA, and $100 \mu \mathrm{g} / \mathrm{ml}$ tRNA. The membrane was washed twice at room temperature for $5 \mathrm{~min}$ with $2 \times$ SSC $/ 0.1 \%$ SDS, twice at room temperature with $0.2 \times$ SSC $/ 0.1 \%$ SDS for $5 \mathrm{~min}$, and $15 \mathrm{~min}$ at $42^{\circ} \mathrm{C}$ with $0.2 \times \mathrm{SSC} / 0.1 \%$ SDS. The membrane was 
SS

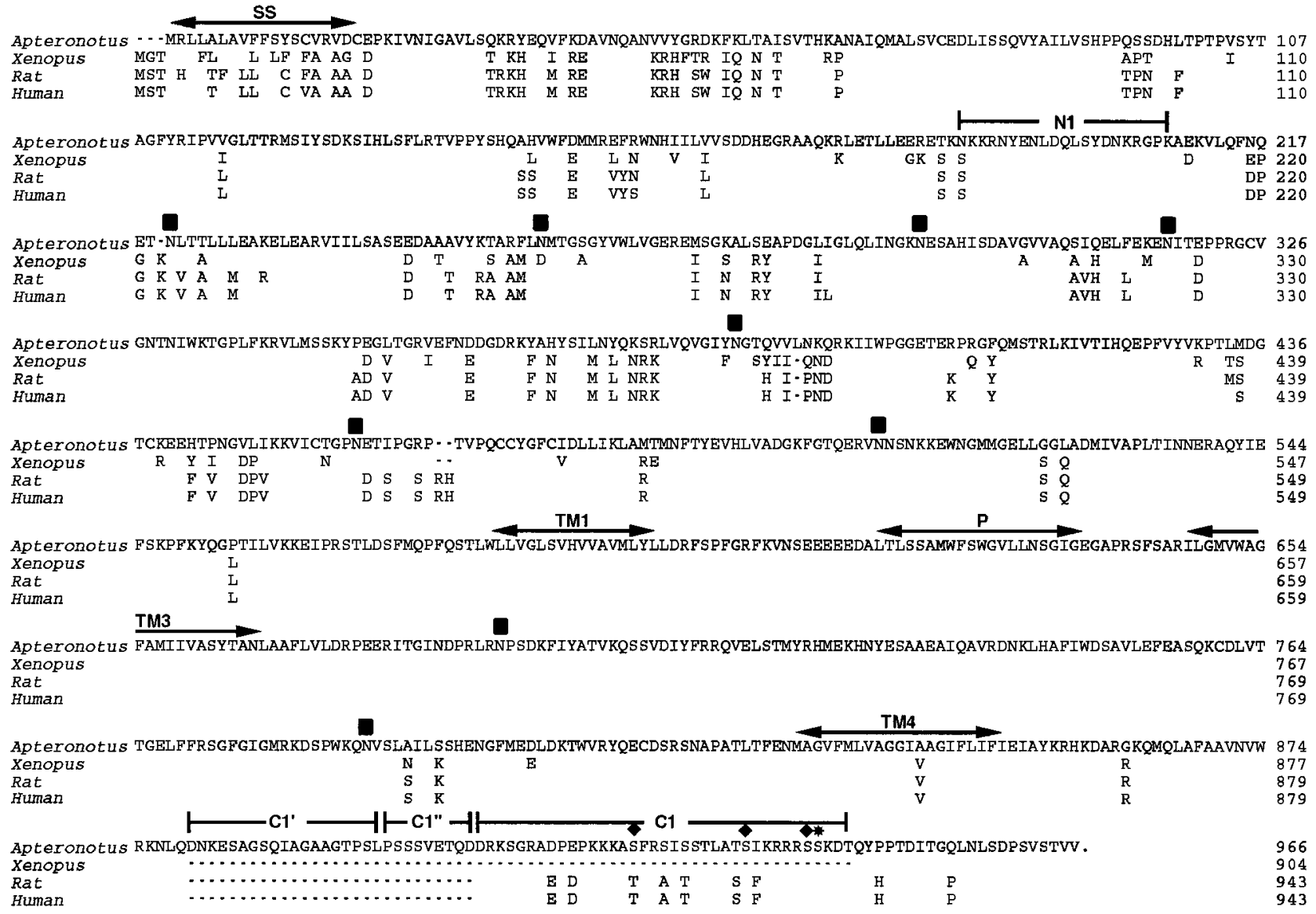

Figure 1. Sequence comparison of the NR1 proteins. The Apteronotus NR1 protein sequence is shown and compared with NR1 sequences of Xenopus (Soloviev et al., 1996), rat (Anantharam et al., 1992), and human (Foldes et al., 1993; Karp et al., 1993; Planells-Cases et al., 1993). Residues that are identical to the aptNR1 sequence are omitted in the other sequences. Positions of deletions are indicated by dashes. The amino acid positions are indicated on the right. TM1,TM3, and TM4 indicate the putative transmembrane segments, and $P$ indicates the proposed pore segment. Glycosylation ( filled squares), protein kinase C ( filled diamonds), and protein kinase A ( filled star) are indicated above the aptNR1 sequence. N1, C1, C1', and C1" indicate the positions of the alternatively spliced cassettes.

exposed overnight to $\mathrm{x}$-ray film (BioMax MR, Kodak) with an intensifier screen at $-80^{\circ} \mathrm{C}$.

\section{In situ hybridization}

In situ hybridization was performed by using a modified version of the protocol of Simmons et al. (1989) as described previously (Bottai et al., 1997). For the N1 cassette an RNA probe was transcribed from a $77 \mathrm{bp}$ (nt 579-656) segment of NR1 cDNA that was amplified by PCR with the primers Dano 10 and 11 . The probe for the $\mathrm{C} 1$ cassette experiment was transcribed from an 87-bp-long NR1 cDNA fragment (nt 2764-2851; primers Dano 23 and 24). All glassware was baked for $4 \mathrm{hr}$ at $250^{\circ} \mathrm{C}$; distilled water for all solutions was treated with $0.1 \%$ diethylpyrocarbonate (DEPC) and then autoclaved.

After hybridization the slides were air-dried and apposed to x-ray film (Kodak BioMax MR film); after 2-5 d the film was developed, and the slides were dipped in emulsion (1:1 dilution of NTB2 gel in $600 \mathrm{~mm}$ ammonium acetate) and exposed for $15 \mathrm{~d}$. The slides were developed and lightly counterstained with neutral red. Approximately one-half of the slides routinely were coverslipped with Permount; the other one-half were coverslipped with glycerol in PBS to permit the use of differential interference contrast (DIC) microscopy, which facilitated the identification of specific cell types.

Slide autoradiographs were photographed on an Olympus microscope, and the film was scanned (1500 dpi; Polaroid SprintScan). Montages were made with Photoshop 4 and Illustrator 7. Cell groups were identified with reference to an atlas of the brain of A. leptorhynchus (Maler et al., 1991). The only image processing used was to adjust the output range in Photoshop to match the input range. Quantitative analysis was done on the emulsion-coated material. Individual cells were selected under DIC; grain counts and cell areas were measured, and grain densities were computed with National Institutes of Health Image software. Background grain densities (measured in the sense controls) were subtracted from all measurements. The results were analyzed by ANOVA, using Statistica on a Macintosh computer.

\section{RESULTS}

\section{Sequence conservation of NR1 proteins expressed by fish and mammals}

The NR1 cDNAs were identified from Apteronotus cDNA libraries by hybridization with rat NR1 probes. Initially, two cDNAs were recovered, encoding $1.2 \mathrm{~kb}$ of sequence at the $5^{\prime}$ region of the mRNA and $1.3 \mathrm{~kb}$ of $3^{\prime}$ sequence that included the $\mathrm{C}$-terminal region of the mRNA and $1175 \mathrm{nt}$ of $3^{\prime}$ nontranslated mRNA sequence. The remainder of the cDNA was obtained by a combination of PCR approaches. The central segment (nt 1576-2543) was isolated by RT-PCR, using primers from the termini of the previously cloned cDNAs. The $5^{\prime}$ terminal sequence was obtained by using the RACE PCR approach (Frohman et al., 1988) to obtain a product of $550 \mathrm{bp}$ that extended the cDNA sequence in the $5^{\prime}$ direction, as described in Materials and Methods. The complete nucleotide sequence of the aptNR1 cDNA has been deposited in GenBank (accession number AF060557).

Figure 1 presents the sequence of aptNR1, the predicted protein product encoded in the sequence of the Apteronotus NR1 


\section{亨}

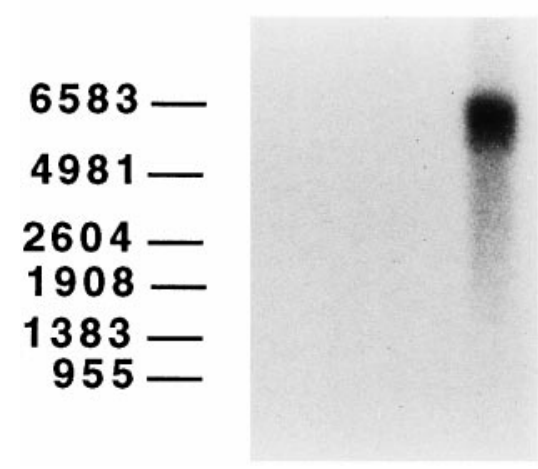

Figure 2. Analysis of aptNR1 mRNAs. RNA samples $(20 \mu \mathrm{g})$ from liver and brain were fractionated by formaldehyde agarose gel electrophoresis, and the Northern blot was probed with a $1.3 \mathrm{~kb}$ fragment of the aptNR1 cDNA. RNA size markers are indicated on the left.

cDNA. The first methionine codon in this sequence is preceded by $29 \mathrm{nt}$ of $5^{\prime}$ nontranslated sequence and is designated as the presumptive initiation codon. The nucleotide sequence context of this methionine codon matches the Kozak consensus sequence at 6 of 10 positions (agCACaAUGc), including the critical adenosine residue at position -3 (Kozak, 1991). This methionine corresponds to the third amino acid of the predicted Xenopus, rat, and human sequences (Moriyoshi et al., 1991; Foldes et al., 1993; Karp et al., 1993; Zimmer et al., 1995; Soloviev et al., 1996), indicating that the fish NMDAR1 protein is slightly shorter at the $\mathrm{N}$ terminus than the previously described NR1 sequences.

Figure 1 illustrates the high level of sequence conservation between aptNR1 and its higher vertebrate homologs. The aptNR1 amino acid sequence, excluding the alternatively spliced exons, is identical at $87.6,88.3$, and $88.7 \%$ positions when compared with Xenopus, rat, and human sequences, respectively. Sequence homologies are most pronounced in the carboxyl half of the protein, where only eight amino acid positions are divergent (homology >98\%) in the segment stretching between aptNR1 amino acid 486 and the site of C-terminal alternative splicing. This highly conserved segment includes the three proposed transmembrane segments, the pore segment and the ligand-binding domains S1 (defined as the 150 amino acids N-terminal to TM1) and S2 (defined as the extracellular loop between TM3 and TM4) (O'Hara et al., 1993; Kuryatov et al., 1994; Stern-Bach et al., 1994). The very high sequence conservation of the segments S1 and S2 in contrast to the much lower sequence conservation at the $\mathrm{N}$ terminus (amino acids 1-485) suggests that strong functional constraints have acted to maintain the sequence and structure of these segments.

Figure 2 illustrates a Northern blot analysis of the aptNR1 mRNA. In this experiment the probe included nucleotides corresponding to the $3^{\prime}$ nontranslated sequence and a short segment (200 nt) of the C-terminal coding sequence, which should hybridize to all forms of the alternatively spliced aptNR1 mRNA described below. The brain mRNAs that hybridize to this probe appear as a broad band of $\sim 6000-7000 \mathrm{nt}$ in length and are absent in the hybridization to liver mRNA. The broad nature of the signal in brain RNA suggests that there is considerable heterogeneity in the lengths of the aptNR1 mRNAs, possibly resulting from a combination of alternative RNA splicing and the use of alternative polyadenylation signals. Alternative RNA splicing within the coding segments of the mRNAs is described below.

\section{N1 alternative RNA splicing in the electric fish CNS}

Mammalian NR1 genes exhibit two alternatively spliced $\mathrm{N}$-terminal splice isoforms that differ in the presence or absence of the short 21 amino acid N1 sequence (Anantharam et al., 1992; Durand et al., 1992; Nakanishi et al., 1992). To determine whether N1 alternative RNA splicing is conserved in Apteronotus, we identified cDNAs for both alternatively spliced transcripts for aptNR1, using a PCR approach. Primers flanking the presumed splice junction were used to amplify cDNAs prepared from Apteronotus brain RNA; two PCR products were obtained. DNA sequence analysis confirmed that these represented the fish homologs of the $\mathrm{N}^{-}$and $\mathrm{N}^{+}$variants observed for mammalian NR1 subunits. Analysis of the intensity of these two PCR products after electrophoresis indicated that the $\mathrm{N} 1^{-}$form was 5-10 times more abundant than the $\mathrm{N}^{+}$form. As shown in Figure 1, 20 of the 21 amino acids of the aptNR1 N1 sequence are identical to those found in Xenopus, rat, and human NMDAR1, which identifies the N1 insert sequence as one of the most highly conserved segments within the $\mathrm{N}$-terminal region of the protein.

To provide a more reliable estimate for the relative amounts of $\mathrm{N} 1{ }^{-}$and $\mathrm{N}^{+}$mRNAs than the estimate obtained from the PCR assay, we analyzed selected brain regions, using an RNase protection assay that differentiated between the two splice isoforms. The RNA probe was complementary to $446 \mathrm{nt}$ of aptNR1 mRNA that included the $63 \mathrm{nt} \mathrm{N} 1$ sequence (Fig. $3 A$ ). The mRNAs containing the $\mathrm{N}^{+}{ }^{+}$insert were predicted to protect the full 446 nt of this probe, whereas $\mathrm{N}^{-}{ }^{-}$mRNAs should protect two smaller fragments of 156 and 227 nt. Figure $3 B$ illustrates the results obtained when this assay was applied to RNAs prepared from different brain regions. Quantitation of the relative amounts for $\mathrm{N}^{-}$and $\mathrm{N}^{+}{ }^{+}$are given in Table 1 . With total brain RNA, strong signals were detected for both the $\mathrm{N}^{+}$and $\mathrm{N} 1^{-}$products, with the $\mathrm{N} 1{ }^{-}$form approximately five times more abundant than the $\mathrm{N} 1{ }^{+}$form. In control assays, no signal was detected in the liver RNA sample.

Although the $\mathrm{N}^{-}$form is predominant in all regions of the brain, the relative amount of the $\mathrm{N}^{+}$form varies between regions such that the relative amounts of $\mathrm{N}^{+}{ }^{+}$transcript increase in more caudal regions of the brain, from a level of $18 \%$ in forebrain to $43 \%$ in brainstem. The hypothalamus expresses a low level of the $\mathrm{N}^{+}$mRNA. In the electrosensory relay nucleus (ELL), where we have shown previously that pyramidal cells express high levels of aptNR1 mRNA (Bottai et al., 1997), the $\mathrm{N} 1{ }^{+}$insert is present in approximately one-fourth of these transcripts. This result indicates that the first steps of electrosensory processing involve a significant fraction of the NMDA receptors with properties that depend on the presence of the N1 peptide insert.

The cerebellum of Apteronotus contains a only a small amount of aptNR1 mRNA, $<1 \%$ of the amount in forebrain (Bottai et al., 1997). To facilitate the analysis of the N1 splicing in cerebellum, we increased the amount of input RNA fourfold for the RNase protection experiment (Fig. 3B). The results show that, although the NR1 gene is expressed at only low levels in cerebellum, 50\% of the NR1 mRNAs contain the N1 insert, a ratio that is higher than in any other brain area. In addition, a novel fragment of $\sim 200 \mathrm{nt}$ is detected in the cerebellar RNA. This fragment also is 
A

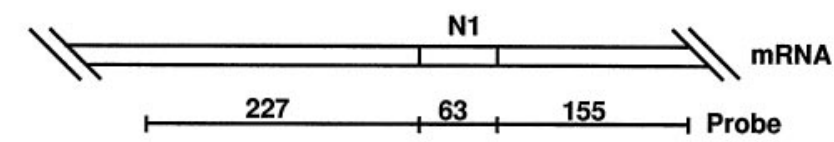

Protected fragments
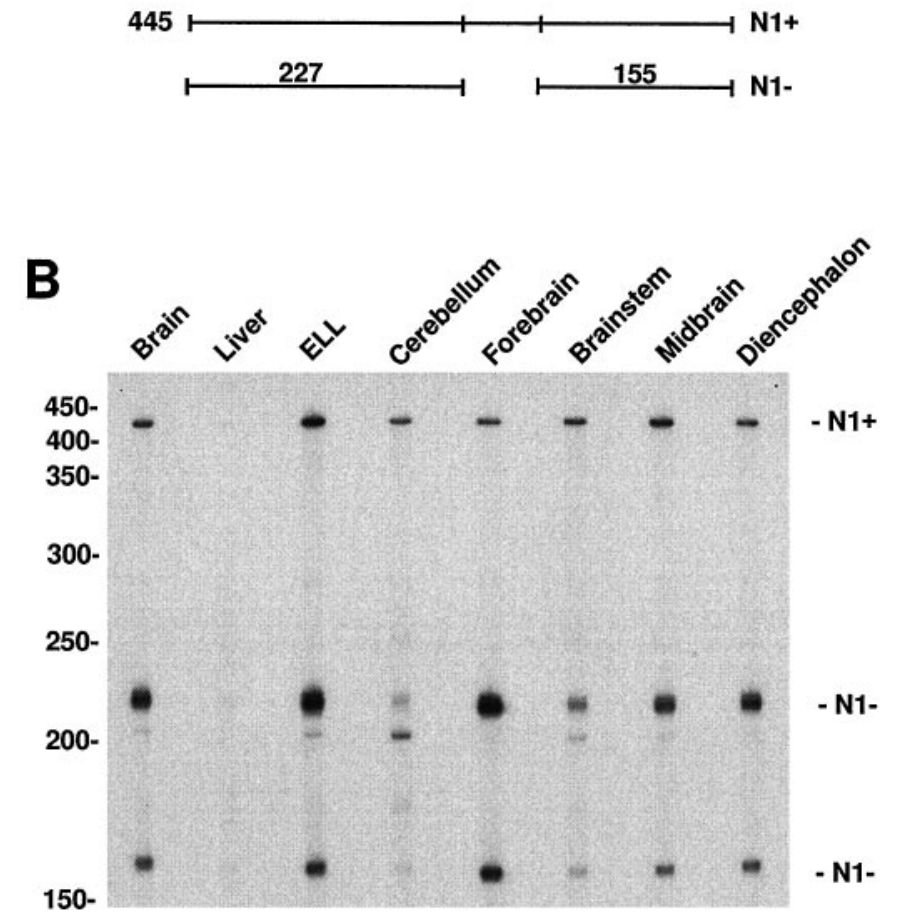

Figure 3. Estimation of the relative amounts of $\mathrm{N} 1^{+}$and $\mathrm{N} 1^{-} \mathrm{NR} 1$ mRNA in various regions of the Apteronotus CNS. A, Schematic representation of the RNase protection assay. AptNR1 mRNA is shown at the top as a double line. The structures of the probe and products are shown below as single lines. The length of each fragment is given in nucleotides. $B$, The products of RNase protection analysis with RNA isolated from different regions of the Apteronotus brain were analyzed by electrophoresis on a $5 \%$ polyacrylamide gel. RNA $(5 \mu \mathrm{g})$ was used in each assay, except for ELL and cerebellum, which used $20 \mu \mathrm{g}$ each. DNA size markers are indicated on the left. The splice isoforms to which the bands correspond are indicated on the right.

detected at lower levels in the ELL, brainstem, and midbrain samples. The absence of this band in both the liver and forebrain assays indicates that it is not an artifact of the protection assay. The identify of this fragment is unknown, but it may represent a novel splice isoform of aptNR1 expressed in cerebellum and brainstem neurons.

\section{Novel isoforms of aptNR1 generated by alternative RNA splicing within the $\mathbf{C}$-terminal region}

Mammalian NR1 transcripts are subject to two separate alternative RNA splicing events within the region encoding the $\mathrm{C}$ terminus of the receptor. Consequently, mammalian NR1 mRNAs either lack or include two short segments, one encoding 37 amino acids (segment $\mathrm{C} 1$ ) that occurs close to the $\mathrm{COOH}$ terminus, and the second encoding 38 amino acids (segment $\mathrm{C} 2$ ) that lies at the $\mathrm{COOH}$ terminus. The presence or absence of segment $\mathrm{C} 2$ determines which of two alternative sequences make up the $\mathrm{C}$ terminus of the protein.

In our initial screen of the fish cDNA library, a total of four
Table 1. Relative levels of the alternatively spliced NR1 mRNAs in different brain areas

\begin{tabular}{lcc} 
Tissue & $\mathrm{N}^{+}(\%)$ & $\mathrm{C}^{+}(\%)$ \\
\hline Brain & 17 & 9 \\
ELL & 24 & 12 \\
Cerebellum & 50 & 5 \\
Forebrain & 8 & 13 \\
Brainstem & 43 & 6 \\
Midbrain & 31 & 10 \\
Hypothalamus & 15 & 24
\end{tabular}

The levels of the $\mathrm{N}^{+}$and $\mathrm{C}^{+}$mRNAs are expressed as a percentage of the total NR1 mRNA from the relative densities illustrated in Figures $3 B(\mathrm{~N} 1)$ and $5 B(\mathrm{C} 1)$. The relative amounts of radioactivity in each band were estimated by densitometry of the autoradiographic films, using a SciScan 500 densitometer (United States Biochemical, Cleveland, $\mathrm{OH}$ ). The signals were adjusted to account for the different lengths and numbers of labeled cytidine residues in each transcript to obtain the values reported.

independent cDNAs containing sequences for the C-terminal region of aptNR1 were obtained, all lacking both the $\mathrm{C} 1$ and $\mathrm{C} 2$ segments. This result suggested that the $\mathrm{C} 1$ and $\mathrm{C} 2$ alternatively spliced forms are present at low levels, if at all, in the Apteronotus brain. To determine whether even rare mRNAs containing $\mathrm{C} 1$ and $\mathrm{C} 2$ are present in the population of aptNR1 mRNAs, we undertook a PCR approach by using primers flanking the putative $\mathrm{C} 1$ and $\mathrm{C} 2$ insertion sites (see Materials and Methods). The DNA sequences of the products recovered from this experiment revealed the presence of three alternative splice segments, which we have labeled C1, C1', and C1" in Figure 1. The cassette labeled C1 encodes a 37 amino acid peptide with high sequence homology to the $\mathrm{C} 1$ cassette described for mammalian NR1 mRNAs. The two other cassettes encode novel sequences not found in the mammalian homologs. The most abundant product from the PCR amplification lacked all three of these inserts. We did not find evidence for additional splice isoforms encoding the $\mathrm{C} 2$ cassette found in mammalian NR1 proteins.

The PCR screen described above uncovered two novel segments that have not been reported in mammalian NR1 genes. To provide additional evidence for the presence of these segments in fish brain RNA, we performed an RNase protection assay with an antisense RNA probe complementary to the mRNA encoding $\mathrm{C} 1{ }^{\prime}-\mathrm{C} 1{ }^{\prime \prime}-\mathrm{C} 1$, as outlined in Figure $4 A$. In agreement with the PCR analysis discussed above, the sizes of the protected fragments confirm the presence of four splice isoforms: $\mathrm{C} 1, \mathrm{C} 1^{\prime}-\mathrm{C} 1{ }^{\prime \prime}$, $\mathrm{C}^{\prime \prime}-\mathrm{C} 1$, and $\mathrm{C}^{\prime}{ }^{\prime}-\mathrm{C} 1{ }^{\prime \prime}-\mathrm{C} 1$ (Fig. $4 B$ ). This result, and the failure to detect a segment homologous to $\mathrm{C} 2$ in the PCR experiment, indicates considerable evolutionary variability in $\mathrm{C}$-terminal RNA splice cassettes of NR1.

The $\mathrm{C} 1$ splice insert contains recognition sites for both protein kinases $\mathrm{A}$ and $\mathrm{C}$ and therefore may be an important modulation site for the NMDA receptor. To determine whether the presence of the $\mathrm{C} 1$ splice cassette is regulated in fish neurons, we used RNase protection analysis to determine the distribution of the $\mathrm{C} 1$ cassette in different brain subregions. The probe extended from the beginning of the $\mathrm{C} 1$ segment through the $\mathrm{C}$-terminal region and into the $3^{\prime}$ nontranslated sequence of the aptNR1 mRNA. Protection of this probe by $\mathrm{C}^{+}{ }^{+}$and $\mathrm{C}^{-}$mRNAs yields fragments of 325 and $230 \mathrm{nt}$, respectively. The results of the RNase protection assays are shown in Figure 5. As predicted from the PCR analysis, the amount of $\mathrm{C}^{+}$mRNA was generally much lower than that of the $\mathrm{C}^{-}$isoform, with levels of $9 \%$ estimated for whole brain RNA (Table 1). In general, the inclusion of $\mathrm{Cl}^{+}$ 
A
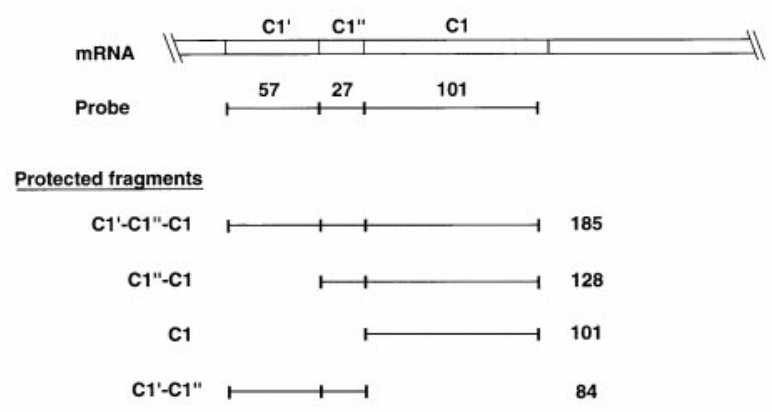

B

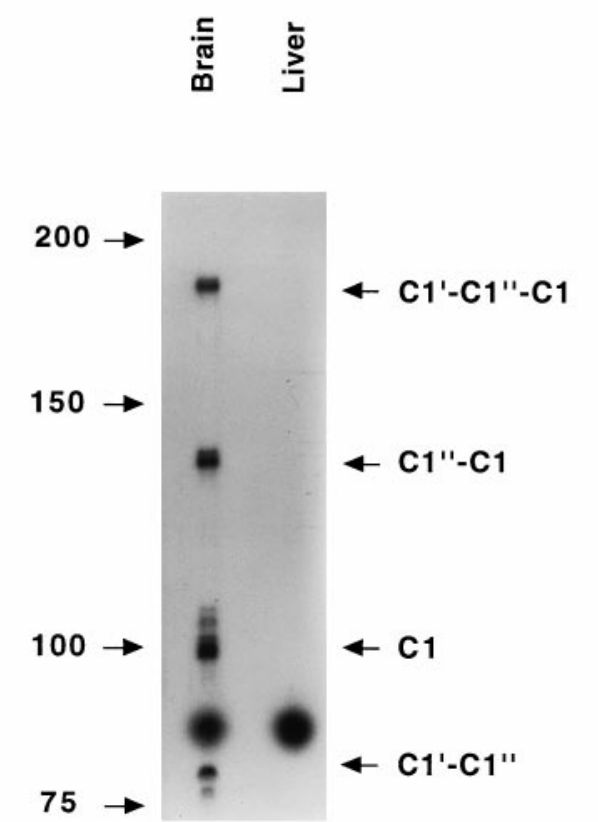

Figure 4. RNase protection analysis confirms the presence of novel NR1 splice isoforms containing cassettes $\mathrm{C}^{\prime}$ and $\mathrm{C}^{\prime \prime}$. $A$, Schematic representation of the RNase protection assay. AptNR1 mRNA is shown at the top as a double line. The structures of the probe and products are shown below as single lines. The length of each fragment is given in nucleotides. $B$, The products of RNase protection analysis with RNA $(20 \mu \mathrm{g})$ isolated from Apteronotus brain and liver were analyzed by electrophoresis on a 5\% polyacrylamide gel. DNA size markers are indicated on the left. The splice isoforms to which the bands correspond are indicated on the right.

cassette varied in an opposite manner to that observed for the $\mathrm{N}^{+}$cassette, $\mathrm{Cl}^{+}$being higher in forebrain and lower in more caudal areas. However, because the assays used do not measure directly the presence or absence of both exons in an individual mRNA, we have not been able to determine directly whether there is a coordinate regulation of the two alternatively spliced exons. Hypothalamus recorded the highest ratio of $\mathrm{Cl}^{+}$containing NR1 transcripts.

In the studies described above, we were unable to detect the presence of the $\mathrm{C} 2$ splicing cassette that is a prevalent isoform of mammalian NMDAR1 mRNAs. As an approach to isolation of
A

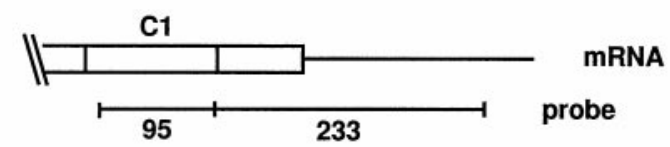

Protected fragments
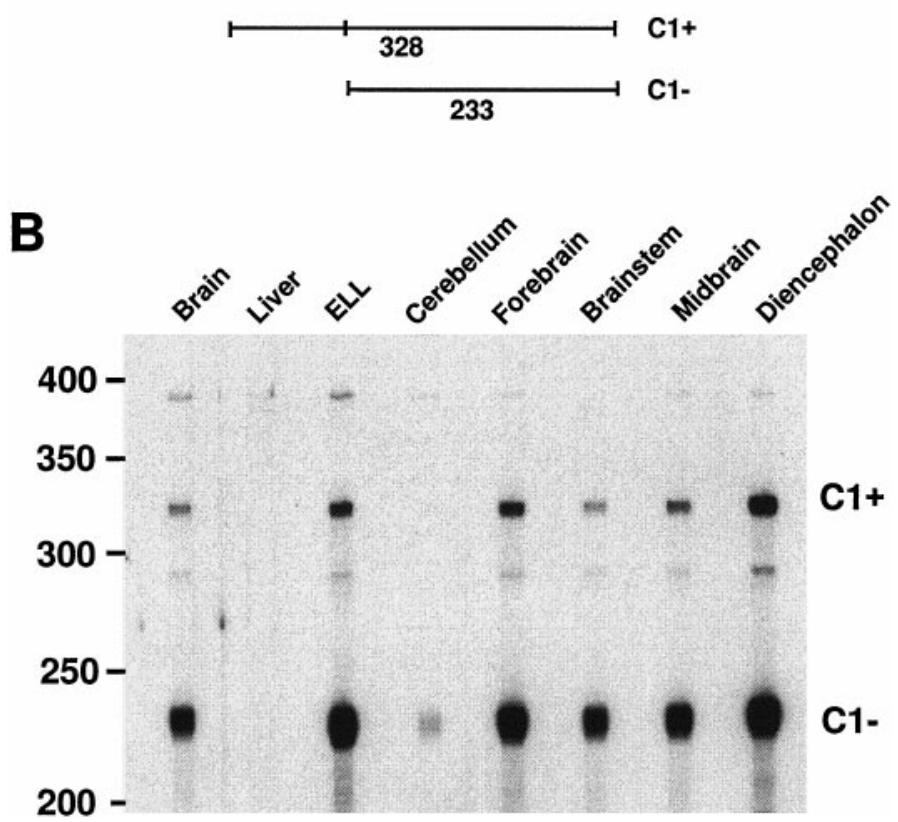

Figure 5. Estimation of the relative amounts of $\mathrm{C}^{+}{ }^{+}$and $\mathrm{C} 1^{-} \mathrm{NR} 1$ mRNA in various regions of the Apteronotus CNS. $A$, Schematic representation of the RNase protection assay. AptNR1 mRNA is shown at the top as a double line. The structures of the probe and products are shown below as single lines. The length of each fragment is given in nucleotides. $B$, The products of RNase protection analysis with RNA isolated from different regions of the Apteronotus brain were analyzed by electrophoresis on a $5 \%$ polyacrylamide gel. RNA $(5 \mu \mathrm{g})$ was analyzed in each assay, except for ELL, which used $20 \mu \mathrm{g}$. DNA size markers are indicated on the left. The splice isoforms to which the bands correspond are indicated on the right.

the fish C2 sequence, an RT-PCR amplification was performed to identify fragments spanning the $\mathrm{C} 1$ cassette and extending into the $3^{\prime}$ untranslated sequence of aptNR1. In this amplification the presence of a sequence homologous to $\mathrm{C} 2$ is predicted to produce a product larger than the product obtained from the $\mathrm{C}^{+}$splice variant described above. Analysis of the products of this amplification by using Southern blot hybridization with a probe that hybridized with all of the splice variants showed only a single product, corresponding to the $\mathrm{C}^{+}{ }^{+} \mathrm{C}^{-}$isoform (data not shown). In summary, these results have failed to find evidence for the existence of the $\mathrm{C} 2$ splice cassette in fish NR1 mRNA.

\section{Cell-specific splicing of the NR1 transcript in neurons of the electrosensory system}

To determine which specific neuronal populations in the electrosensory system express the alternatively spliced NR1 mRNAs, we performed in situ hybridizations on coronal sections of the Apteronotus brain with probes specific for N1 and C1. Labeling with these probes was distributed specifically over gray matter regions, with no label detected in fiber tracts. Control probes representing sense strands of both $\mathrm{N} 1$ and $\mathrm{C} 1$ produced only a very low and homogenous distribution of grains (data not shown).

The electroreceptive inputs from skin receptors project to the 
ELL nucleus of the medulla, which is the primary processing station for electrosensory information. Tuberous electroreceptors encode the amplitude of the electric organ discharge (EOD) through excitatory glutamatergic synapses to the large ELL pyramidal cells and smaller ELL granule cell interneurons. Additional excitatory glutamatergic synaptic inputs to both of these cell types arise from feedback pathways that originate higher in the CNS and terminate on the prominent apical dendrites of pyramidal cells (Bastian, 1993; Wang and Maler, 1994; Berman et al., 1997). The ELL pyramidal cells express NR1 mRNA to a very high level (Bottai et al., 1997) and are labeled strongly with both $\mathrm{N} 1$ and $\mathrm{C} 1$ probes (Fig. 6I, Table 2), indicating that both splice cassettes contribute to NMDA receptor populations in these cells. The major class of inhibitory interneuron in the ELL is the type 1 granule cells, which provide inhibitory inputs to the pyramidal cells that contribute to temporal filtering in this system. These granule cell interneurons express moderate levels of NR1 mRNA that is labeled with both the pan NR1 probe and the N1-specific probe but shows no detectable label with the $\mathrm{C} 1$ probe (Fig. 6I). This result indicates that pyramidal cell projection neurons contain NMDA receptors that are regulated via both the $\mathrm{N} 1$ and $\mathrm{C} 1$ regulatory domains, whereas the granule cell interneuron NMDA receptors specifically lack the $\mathrm{C} 1$ form.

Pyramidal cells of the ELL transmit electrosensory signals via projections to two secondary processing nuclei, the midbrain torus semicircularis and the hindbrain nucleus praeminentialis. The N1 probe labeled neurons to moderate levels in both of these nuclei, as did the pan NR1 probe. In contrast, the C1 probe demonstrated a only very weak labeling in both nuclei (Fig. 6II). The relatively low level of $\mathrm{C} 1$ splicing in these areas suggests that $\mathrm{C} 1$-mediated regulation of NMDA receptors in these secondary nuclei may be less important than it is in the primary processing areas of the ELL.

Electrosensory and visual signals are combined and compared in the optic tectum of the electrosensitive teleost brain. We previously detected only low levels of NMDA receptor expression in most tectal neurons, except for the pyramidal cells of the stratum fibrosum et griseum superficiale. These cells have dendrites that receive signals from both electrosensory and visual systems and are thought to be important for the integration of information from both systems. Although these pyramidal cells are intensely labeled by the pan NR1 probe, they are labeled only very weakly by either the $\mathrm{N} 1$ or $\mathrm{C} 1$ probes (Table 2). Although the $\mathrm{N} 1$ probe weakly labeled most pyramidal cells, the $\mathrm{C} 1$ probe appeared to label only a subset (approximately one-half) of these cells (the mean density given in Table 2 includes only labeled cells).

Electrosensory information also is projected to forebrain, although the pathways of these projections are not well defined. The RNase protection assay indicated that the N1 splice is expressed at low levels in forebrain; consistent with this, in situ hybridization also revealed a homogenous low level of expression of the N1 splice that paralleled the expression of NR1 pan (data not shown). The RNase protection experiment indicated that cells in the forebrain contain low levels of $\mathrm{C}^{+}$mRNA (comparable to ELL; see Table 1). Labeling with the $\mathrm{C} 1$ probe in forebrain was heterogeneous and confined mainly to two forebrain regions: ventral intermediate region and the dorsal posterior forebrain. Both regions may be involved in electrocommunication behavior (Wong, 1997). The significance of this localized expression of the $\mathrm{C} 1$ splice is unclear, because specific roles for different forebrain areas in processing of electrosensory signals have not been defined.

The control of the electric organ discharge is influenced by electrosensory information via a neuronal network that extends from the nucleus electrosensorius to the thalamic prepacemaker nucleus and finally to the pacemaker nucleus (containing pacemaker and relay cells), which directly control spinal electromotor neurons. Neurons in all three of these nuclei contain low-tomoderate levels of NR1 mRNA detected with the pan NR1 probe and uniformly low levels of $\mathrm{N} 1$ insert detected with the $\mathrm{N} 1$ probe. A much more heterogeneous pattern was observed by using the $\mathrm{C} 1$ probe. Neurons of the nucleus electrosensorius and the prepacemaker nucleus showed no label with the $\mathrm{C} 1$ probe. However, in the final stage of the control pathway, the medullar pacemaker nucleus, relay cells were strongly labeled with $\mathrm{C} 1$, whereas adjacent pacemaker cells were not labeled (Fig. 6III). These results indicate that only NMDA receptors in the relay cell, the final cell of this motor control pathway, contain the $\mathrm{C} 1$ regulatory segment.

\section{DISCUSSION}

\section{Evolution of the teleost NR1 sequence}

The fish NR1 sequence reported here is the first complete teleost NMDA receptor subunit sequence to be established and represents the most evolutionarily distant NR1 sequence to date. Phylogenetic comparison to human, rodent, avian, and Xenopus sequences confirms the relatively distant evolutionary origin of the fish sequence (Fig. 7), which is clearly evident in the amino acid sequence comparisons shown in Figure 1. When compared with the mammalian sequences, the fish NR1 displays twice the number of amino acid nonidentities than does the Xenopus NR1 (Soloviev et al., 1996). A striking aspect of the evolution of the NR1 gene is that, except for the C-terminal splice cassettes, sequence variation is restricted mostly to the N-terminal 470 amino acid residues. The sequence of the C-terminal half of the protein, including the proposed transmembrane, ion pore, and glycine-binding segments, is conserved very highly between the fish and mammalian sequences. Thus the ligand-binding properties and pharmacology of aptNR1 should match closely those of mammalian NR1, because all of the residues known to participate in binding glycine (Laube et al., 1993; Kuryatov et al., 1994; Wafford et al., 1995; Hirai et al., 1996) are conserved in the fish sequence. On the other hand, the high sequence divergence of the $\mathrm{N}$-terminal segment suggests that it may form a surface domain of the receptor, in which more variation of sequence is tolerated (Wilson et al., 1977). One segment within the divergent $\mathrm{N}$-terminal region that does not diverge is the 21 amino acid alternative RNA splice cassette N1, in which 20 amino acids are identical in all four species (see Fig. 1). This result and the well conserved regulation of N1 splicing discussed below strongly suggest that the controlled expression of NR1 subunits containing N1 is an important feature of NMDA receptor function.

In the proposed topological models of the NR1 subunit, the segment $\mathrm{C} 0$ is the intracellular 30 amino acid peptide immediately $\mathrm{C}$-terminal to the final transmembrane segment TM4, where it contributes to the regulation of NMDA receptor activities via interactions with both calmodulin and $\alpha$-actinin (Ehlers et al., 1996; Wyszynski et al., 1997). The C0 sequence has been highly conserved in the fish receptor, with only a single amino acid substitution, suggesting that $\mathrm{C} 0$-mediated regulation of NMDA receptors is also important in fish neurons.

The 37 residue alternatively spliced segment $\mathrm{C} 1$ is also a feature of the fish NR1 gene. The amino acid sequence of the fish 
I
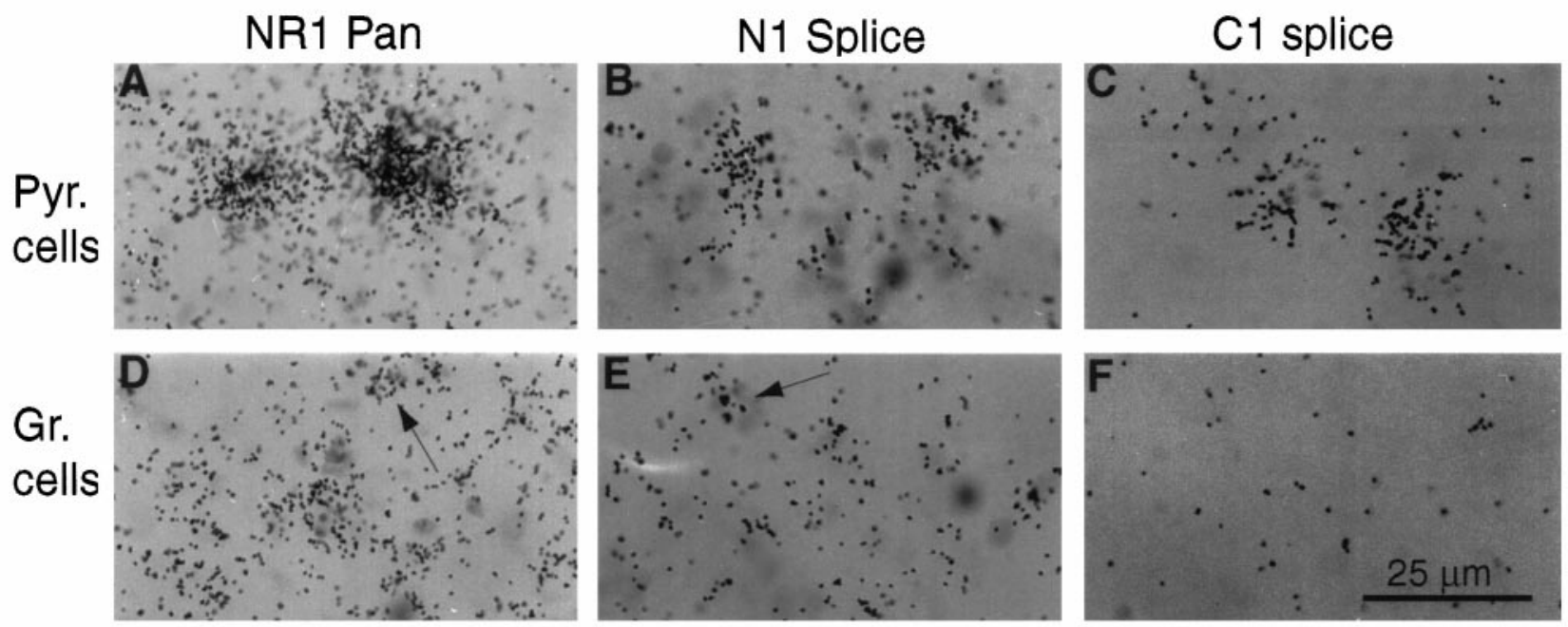

II
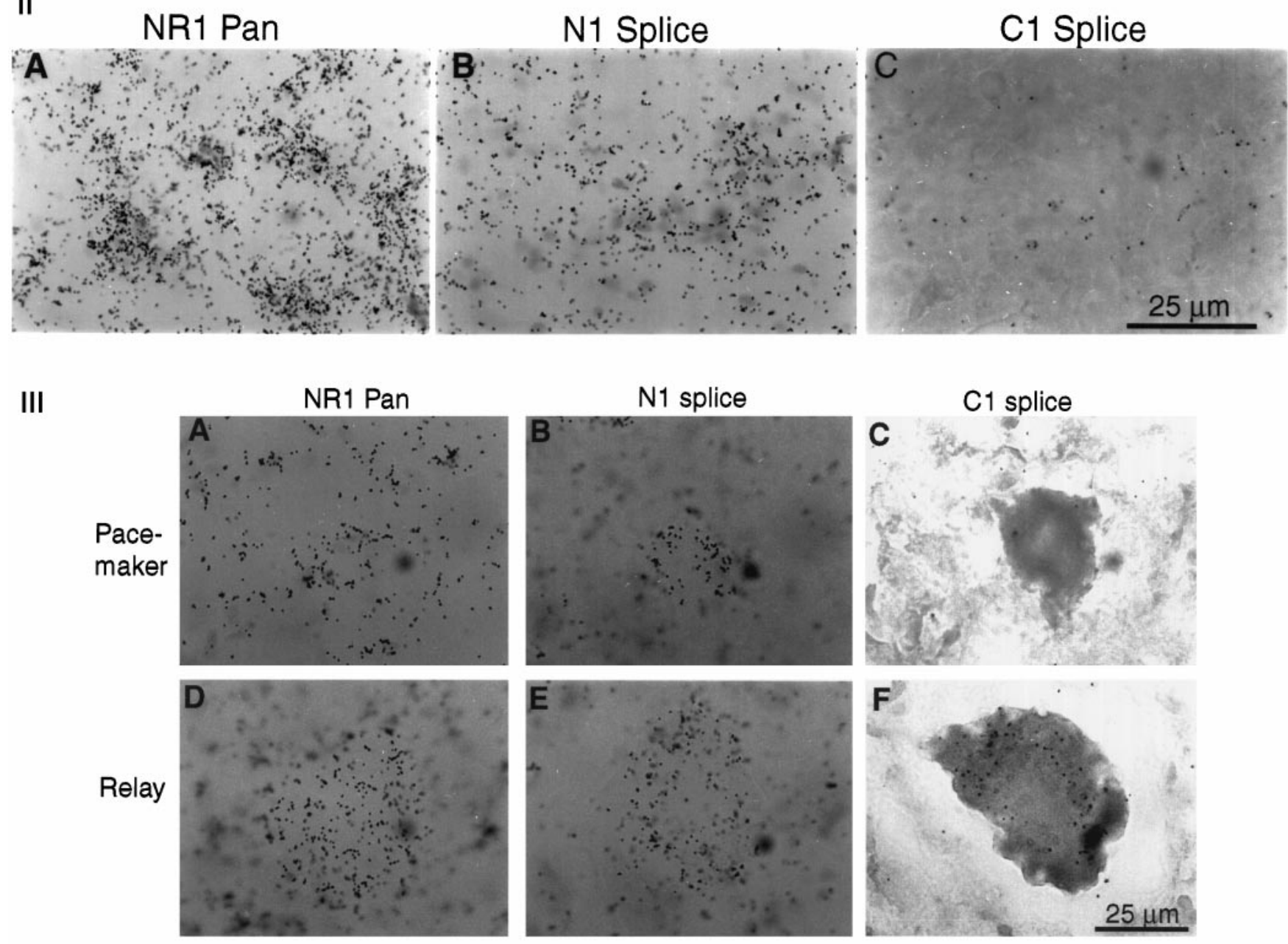

Figure 6. Localization of aptNR1 alternatively spliced transcripts in neurons of the electrosensory system. I, In situ hybridization of NR1 splice variants in the electrosensory lateral line lobe. A, D, Both pyramidal cells (Pyr. cells) and granular interneurons (Gr. cells) of the ELL are labeled with the NR1 pan probe. $B, E$, Pyramidal cells and interneurons also express the $\mathrm{N} 1$ splice cassette. $C, F$, The $\mathrm{C} 1$ splice cassette is expressed in pyramidal cells but appears to be absent from ELL interneurons. II, In situ hybridization of NR1 splice variants in layers 7-8A of the torus semicircularis dorsalis. $A$, The pan probe reveals strong labeling in cells of this region; as previously reported (Bottai et al., 1997), this region of the torus has the highest density of NR1 expression. $B$, The $\mathrm{N} 1$ probe also appears to label most cells, although at a much lower level. $C$, There does not appear to be any specific hybridization with the $\mathrm{C} 1$ probe to neurons in the torus. III, In situ hybridization of NR1 splice variants in the pacemaker nucleus. Pacemaker and relay cells were identified on the basis of somatic diameter in cases in which they were sectioned through their nuclei (relay cells are far larger). $A, D$, Both pacemaker and relay cells are labeled with the NR1 pan probe. $B, E$, Both pacemaker and relay cells also strongly express the N1 splice cassette. $C, F$, The $C 1$ splice cassette appears to be absent from pacemaker cells but is strongly expressed in relay cells. 
Table 2. Corrected grain densities from in situ hybridization studies with probes specific for the N1 and C1 splice isoforms

\begin{tabular}{|c|c|c|c|c|c|c|}
\hline \multirow[b]{2}{*}{ Brain region } & \multicolumn{3}{|l|}{ N1 splice } & \multicolumn{3}{|l|}{ C1 splice } \\
\hline & Density (grains $/ 100 \mu \mathrm{m}^{2}$ ) & SD & $n$ & Density (grains/100 $\mu \mathrm{m}^{2}$ ) & $\mathrm{SD}$ & $n$ \\
\hline DC & 11.2 & 3.2 & 17 & 7.8 & 3.2 & 20 \\
\hline DLd & 12.3 & 3.4 & 24 & ND & - & - \\
\hline $\mathrm{TeO}$ & 7.6 & 2.5 & 22 & 8.4 & 3.5 & 31 \\
\hline nM Crest cells & 17.4 & 4.0 & 26 & 14.5 & 5.4 & 15 \\
\hline ELL pyramidal cells & 25.0 & 6.9 & 26 & 19.1 & 4.9 & 59 \\
\hline ELL granule cells & 20.5 & 4.7 & 51 & ND & - & - \\
\hline
\end{tabular}

Statistics were done by ANOVA with Tukey's unequal $n$ post hoc test.

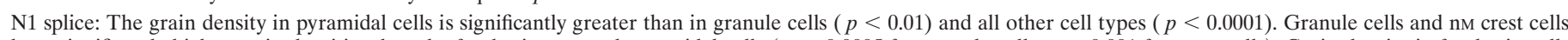

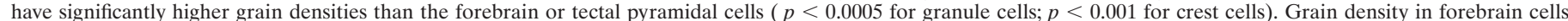

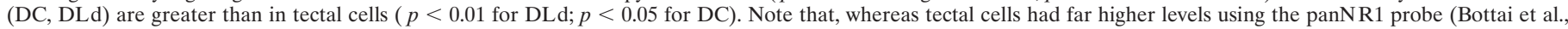

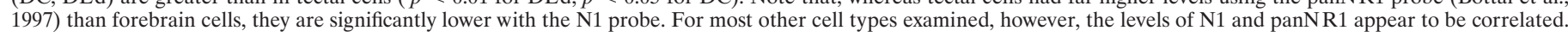

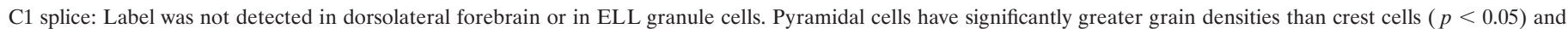

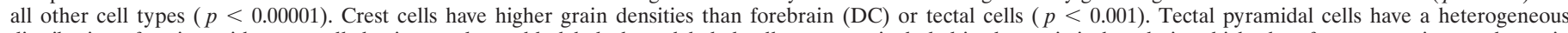

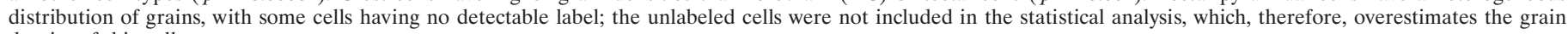
density of this cell type.

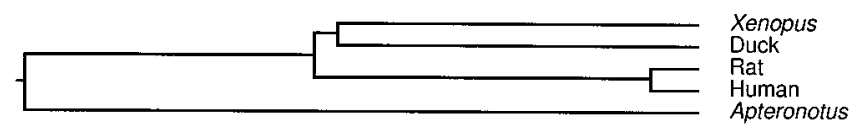

Figure 7. Phylogenetic tree comparing the ancestral relationships among the NR1 protein sequences from Apteronotus, Xenopus (Soloviev et al., 1996), duck (Kurosawa et al., 1994), rat (Moriyoshi et al., 1991), and human (Planells-Cases et al., 1993). The length of each branch is proportional to evolutionary distance. The sequences were aligned by using the multiple sequence alignment program Clustal V in the DNASTAR sequence analysis package.

C1 cassette contains seven amino acid substitutions as compared with the mammalian sequences, but only the serine at position 926 of the fish sequence fails to maintain the charge and hydrophilic character of the mammalian homologs. The mammalian $\mathrm{C} 1$ segment has been shown to contain sites phosphorylated by protein kinase A (PKA) and protein kinase C (PKC) (Tingley et al., 1993, 1997; Hisatsune et al., 1997; Leonard and Hell, 1997). The three PKC and single PKA phosphorylation sites demonstrated in the rat NR1 C1 segment by Tingley et al. (1997) are conserved in the fish sequence (see Fig. 1). The positions of key positive residues and hydroxyl acceptors have been maintained, with only the substitution of serine for threonine at position 923 directly affecting the target sites. Phosphorylation of $\mathrm{C} 1$ inhibits the interaction with calmodulin and subsequent calmodulin inhibition of receptor activity (Ehlers et al., 1996; Hisatsune et al., 1997). The calmodulin interaction sites (Ehlers et al., 1996) on C0 (amino acids 854-879) and C1 (amino acids 919-942) are well conserved in the fish sequence, with only a single substitution in the $\mathrm{C} 0$ site and five amino acid substitutions, four of which are highly conservative, in the $\mathrm{C} 1$ site. This high level of sequence conservation within the putative regulatory domains of the fish $\mathrm{C} 0$ and $\mathrm{C} 1$ segments indicates that many, if not all, of the regulatory mechanisms associated with the mammalian $\mathrm{C} 1$ segment were features of NMDA receptors in primitive vertebrate organisms existing before the divergence of fish and tetrapod lineages.

In heterologous cells expressing NR1, PKC activators increase both NMDA responses and phosphorylation of the NR1 subunit (Durand et al., 1992, 1993; Tingley et al., 1993, 1997; Sigel et al., 1994; Zheng et al., 1997). However, direct involvement of the C1 segment in this process has been questioned because homomeric $\mathrm{NR} 1$ receptors containing $\mathrm{C} 1$ are less responsive than $\mathrm{C}^{-}$re- ceptors to PKC activators (Durand et al., 1993). The presence of C1-containing NR1 subunits in pyramidal cells, but not granule cells, of the ELL (see Fig. 6I), where excitatory synaptic responses are analyzed readily (Berman et al., 1997), provides an opportunity to examine these effects of the $\mathrm{C} 1$ segment on the regulation of NMDA receptors located at functional synapses.

A study of Xenopus NR1 failed to find evidence for either C1 or C2 segments in frog brain RNA (Soloviev et al., 1996). The finding of $\mathrm{C} 1$ in the fish NR1 suggests either that this segment is present at such low abundance in the frog that it was not detected or that the $\mathrm{C} 1$ sequence was present in the ancestral jawed vertebrate but has been lost in the lineage leading to modern frogs.

The most striking evolutionary divergence within the fish NR1 sequence is the presence of the novel segments $\mathrm{C}^{\prime}$ and $\mathrm{C} 1{ }^{\prime \prime}$. These segments were recovered by using an RT-PCR experiment designed to probe for sequences of relatively low abundance in fish brain NR1 mRNA. The presence of these two splice cassettes in a variety of splice isoforms was indicated by DNA sequence analysis of the PCR products and confirmed by an RNase protection analysis (see Fig. 4). The location of $\mathrm{Cl}^{\prime}$ and $\mathrm{C} 1^{\prime \prime}$ between $\mathrm{C} 0$ and $\mathrm{C} 1$ suggests a possible role in the regulation of the calmodulin and $\alpha$-actinin interactions that occur at adjacent sites, possibly via phosphorylation of the multiple serine residues in $\mathrm{C}^{\prime}$ and $\mathrm{C1}^{\prime \prime}$. The presence of these novel sequences within the C-terminal domain of NR1 appears to be an evolutionary development of the teleost lineage that has not been observed in either frog or mammalian NR1 transcripts.

We failed to detect the presence of the $\mathrm{C} 2$ splice cassette in fish NR1 transcripts, using a sensitive PCR and Southern blot procedure. C2 also was not detected in frog brain RNA (Soloviev et al., 1996), suggesting that the alternative splice junction that generates C2 in the mammalian NR1 gene arose after the divergence of the frog and mammalian lineages. The most significant characteristic of the $\mathrm{C} 2$ splice isoform is that it lacks the canonical amino acid sequence S/TXV for recognition by the PSD class of synaptic localization proteins (Sheng and Kim, 1996), whereas the C2' isoforms (including aptNR1) terminate with TVV (Kornau et al., 1995). The absence of the C2 splice isoform means that all NMDA receptors in fish contain NR1 isoforms that participate directly in the PSD interaction. 


\section{Regulation of alternative RNA splicing of NR1 in neurons of the electrosensory system}

Alternative RNA splicing of mammalian NR1 transcripts regulates the presence of the 21 amino acid N1 peptide encoded by exon 5 (Anantharam et al., 1992; Nakanishi et al., 1992; Hollmann et al., 1993). This short peptide contains a high percentage of charged residues and is located adjacent to the ligand-binding domain of the receptor. The presence of the N1 results in NMDA receptors that express higher current amplitudes (Hollmann et al., 1993; Zheng et al., 1994), lower agonist affinities (Nakanishi et al., 1992; Hollmann et al., 1993), resistance to inhibition by extracellular protons (Traynelis et al., 1995), and lack of potentiation by magnesium (Paoletti et al., 1995). These properties suggest that N1-containing receptors should produce larger EPSCs at physiological $\mathrm{pH}$ and undergo more rapid deactivation because of lower agonist affinity.

The regulation of N1 splicing in the teleost brain has the same general pattern as that of mammalian NR1. The total amount of $\mathrm{N} 1$ in fish brain is estimated to be $17 \%$ (see Table 1), which compares very well with the estimates of $20 \%$ for rat brain (Nakanishi et al., 1992). Furthermore, the ratio of N1 is higher in more caudal areas of both fish and rat brains, with the highest ratios in cerebellum for both species. This high degree of evolutionary conservation for splice regulation further supports a fundamental role for N1 in NMDA receptor function.

In the fish brain in situ hybridization study, the pattern of neurons labeled with N1 generally matched the pattern with the use of the pan NR1 probe (Bottai et al., 1997) except that the N1 probe produced lower grain densities. Almost all cells that express NR1 contain at least a low level N1 ${ }^{+}$mRNA. An exception to this general pattern are the pyramidal cells of the optic tectum. These cells labeled heavily with the pan NR1 probe to levels significantly above those of forebrain cells but were labeled only slightly above background with the N1-specific probe (data not shown).

We also have examined the patterns of alternative RNA splicing for the $\mathrm{C}$-terminal segment $\mathrm{C} 1$ in neurons of the fish CNS. The level of C1-containing transcripts measured by RNase protection is low in the fish brain $(9 \%)$ and is distributed in a nonuniform manner that is generally higher in more rostral regions (see Table 1). This pattern also has been observed in rat brain, where $\mathrm{C} 1$ transcripts were highest in forebrain, hippocampus, caudate putamen, and olfactory bulb (Laurie et al., 1995). Apparently, the presence of higher levels of $\mathrm{C} 1$ alternative splicing in these rostral areas has been a feature of the very early vertebrate nervous system.

In situ hybridization that used the $\mathrm{C} 1$-specific probe showed a heterogeneous labeling pattern in many regions of the fish brain. In neurons of the electrosensory system, two clear examples of cell-specific regulation were found. In the ELL, expression of the $\mathrm{C} 1$ sequence was restricted to pyramidal cells and was not detectable in adjacent granule cells (see Fig. 6I, Table 2). Pyramidal cells are the major integrative elements for processing of electrosensory spike trains in the ELL, and the presence of the C1 sequence may provide a mechanism to regulate excitatory currents during signal integration and processing. There is strong binding of both forskolin and phorbol ester associated with the feedback input to pyramidal cells (Maler and Wang, 1997), which is involved in adaptive regulation of electrosensory processing (Bastian, 1995, 1996a,b; Maler and Wang, 1997), suggesting that modulation of NMDA receptor currents by PKA and/or PKC may be involved in this process. Granule cells, which provide inhibitory relays to the pyramidal cells, may not require similar regulation of excitatory inputs. Thus in the ELL, neuron-specific regulation of alternative RNA splicing controls the availability of C1-mediated regulatory mechanisms in two of the major cell types in this neuronal network.

The pacemaker nucleus is the second example of cell-specific regulation of the $\mathrm{C} 1$ splice insert. In this nucleus only the relay cells express the $\mathrm{C} 1$ isoform of NR1, whereas pacemaker cells express the $\mathrm{C}^{-}$form. Pacemaker and relay cells receive glutamatergic input from three different sources, and these inputs subserve distinct electrocommunicatory behavior (Heiligenberg et al., 1996). Inputs to both cell types involve NMDA receptors that mediate slow increases in EOD frequency, so it will be interesting to determine whether the presence of the $\mathrm{C} 1$ isoform in relay cells confers different kinetic and/or regulatory properties to the relay cell input.

The sequence and regulation of the $\mathrm{N} 1$ and $\mathrm{C} 1$ splice cassettes are remarkably well conserved in the fish NR1 subunit gene. Further, in the electrosensory system the splicing of the $\mathrm{C} 1$ cassette and, therefore, C1-mediated modulation of NMDA receptor currents are restricted to synapses on the pyramidal cells in the ELL. The well characterized anatomy and physiology of the early steps in signal processing in the ELL now provide an opportunity to investigate the role of $\mathrm{C} 1$ modulation in this process.

\section{REFERENCES}

Anantharam V, Panchal RG, Wilson A, Kolchine VV, Treistman SN, Bayley H (1992) Combinatorial RNA splicing alters the surface charge on the NMDA receptor. FEBS Lett 305:27-30.

Bastian J (1993) The role of amino acid neurotransmitters in the descending control of electroreception. J Comp Physiol [A] 172:409-423.

Bastian J (1995) Pyramidal cell plasticity in weakly electric fish: a mechanism for attenuating responses to reafferent electrosensory inputs. J Comp Physiol [A] 176:63-73.

Bastian J (1996a) Plasticity in an electrosensory system. I. General features of a dynamic sensory filter. J Neurophysiol 76:2483-2496.

Bastian J (1996b) Plasticity in an electrosensory system. II. Postsynaptic events associated with a dynamic sensory filter. J Neurophysiol 76:2497-2507.

Berman NJ, Plant J, Turner RW, Maler L (1997) Excitatory amino acid receptors at a feedback pathway in the electrosensory system: implications for the searchlight hypothesis. J Neurophysiol 78:1869-1881.

Bottai D, Dunn RJ, Ellis W, Maler L (1997) N-methyl-D-aspartate receptor $1 \mathrm{mRNA}$ distribution in the central nervous system of the weakly electric fish Apteronotus leptorhynchus. J Comp Neurol 389:65-80.

Buller AL, Larson HC, Schneider BE, Beaton JA, Morrisett RA, Monaghan DT (1994) The molecular basis of NMDA receptor subtypes: native receptor diversity is predicted by subunit composition. J Neurosci 14:5471-5484.

Chomczynski P, Sacchi N (1987) Single-step method of RNA isolation by acid guanidinium thiocyanate-phenol-chloroform extraction. Anal Biochem 162:156-159.

Collingridge GL, Bliss TV (1995) Memories of NMDA receptors and LTP. Trends Neurosci 18:54-56.

Daw NW, Stein PS, Fox K (1993) The role of NMDA receptors in information processing. Annu Rev Neurosci 16:207-222.

Dunah AW, Yasuda RP, Wang YH, Luo JH, Davilagarcia MI, Gbadegesin M, Vicini S, Wolfe BB (1996) Regional and ontogenic expression of the NMDA receptor subunit NR2D protein in rat brain using a subunit-specific antibody. J Neurochem 67:2335-2345.

Durand GM, Gregor P, Zheng X, Bennett MV, Uhl GR, Zukin RS (1992) Cloning of an apparent splice variant of the rat $N$-methyl-Daspartate receptor NMDAR1 with altered sensitivity to polyamines and activators of protein kinase C. Proc Natl Acad Sci USA 89:9359-9363.

Durand GM, Bennett MV, Zukin RS (1993) Splice variants of the $\mathrm{N}$-methyl-D-aspartate receptor NR1 identify domains involved in reg- 
ulation by polyamines and protein kinase C. Proc Natl Acad Sci USA 90:6731-6735.

Ehlers MD, Tingley WG, Huganir RL (1995) Regulated subcellular distribution of the NR1 subunit of the NMDA receptor. Science 269:1734-1737.

Ehlers MD, Zhang S, Bernhadt JP, Huganir RL (1996) Inactivation of NMDA receptors by direct interaction of calmodulin with the NR1 subunit. Cell 84:745-755.

Foldes RL, Rampersad V, Kamboj RK (1993) Cloning and sequence analysis of cDNAs encoding human hippocampus $N$-methyl-Daspartate receptor subunits: evidence for alternative RNA splicing. Gene 131:293-298.

Frohman MA, Dush MK, Martin GR (1988) Rapid production of fulllength cDNAs from rare transcripts: amplification using a single genespecific oligonucleotide primer. Proc Natl Acad Sci USA 85:8998-9002.

Heiligenberg W, Metzner W, Wong C, Keller C (1996) Motor control of the jamming avoidance response of Apteronotus leptorhynchus-evolutionary changes of a behavior and its neuronal substrates. J Comp Physiol [A] 179:653-674.

Hirai H, Kirsch J, Laube B, Betz H, Kuhse J (1996) The glycine binding site of the $N$-methyl-D-aspartate receptor subunit NR1: identification of novel determinants of co-agonist potentiation in the extracellular M3-M4 loop region. Proc Natl Acad Sci USA 93:6031-6036.

Hisatsune C, Umemori H, Inoue T, Michikawa T, Kohda K, Mikoshiba K, Yamamoto T (1997) Phosphorylation-dependent regulation of $N$-methyl-D-aspartate receptors by calmodulin. J Biol Chem 272: 20805-20810.

Hollmann M, Heinemann S (1994) Cloned glutamate receptors. Annu Rev Neurosci 17:31-108.

Hollmann M, Boulter J, Maron C, Beasley J, Pecht G, Heinemann S (1993) Zinc potentiates agonist-induced currents at certain splice variants of the NMDA receptor. Neuron 10:943-954.

Ikeda K, Nagasqwa M, Mory H, Araki K, Sakimura K, Watanabe M, Inoue Y, Mishina M (1992) Cloning and expression of E4 subunits of the NMDA receptor channel. FEBS Lett 313:34-38.

Ishii T, Moriyoshi K, Sugihara H, Sakurada K, Kadotani H, Yokoi M, Akazawa C, Shigemoto R, Mizuno N, Masu M, Nakanishi S (1993) Molecular characterization of the family of the $N$-methyl-D-aspartate receptor subunits. J Biol Chem 268:2836-2843.

Johnson RR, Jiang X, Burkhalter A (1996) Regional and laminar differences in synaptic localization of NMDA receptor subunit NR1 splice variants in rat visual cortex and hippocampus. J Comp Neurol 368:335-355.

Karp SJ, Masu M, Eki T, Ozawa K, Nakanishi S (1993) Molecular cloning and chromosomal localization of the key subunit of the human $N$-methyl-D-aspartate receptor. J Biol Chem 268:3728-3733.

Kornau HC, Schenker LT, Kennedy MB, Seeburg PH (1995) Domain interaction between NMDA receptor subunits and the postsynaptic density protein PSD-95. Science 269:1737-1740.

Kozak M (1991) An analysis of vertebrate mRNA sequences: intimations of translational control. J Cell Biol 115:887-903.

Kurosawa N, Kondo K, Kimura N, Ikeda T, Tsukada Y (1994) Molecular cloning and characterization of avian $N$-methyl-D-aspartate receptor type 1 (NMDA-R1) gene. Neurochem Res 19:575-580.

Kuryatov A, Laube B, Betz H, Kuhse J (1994) Mutational analysis of the glycine-binding site of the NMDA receptor: structural similarity with bacterial amino acid-binding proteins. Neuron 12:1291-1300.

Kutsuwada T, Kashiwabuchi N, Mori H, Sakimura K, Kushiya E, Araki K, Meguro H, Masaki H, Kumanishi T, Arakawa M, Mishina M (1992) Molecular diversity of the NMDA receptor channel. Nature 358:36-41.

Landwehrmeyer GB, Standaert DG, Testa CM, Penney Jr JB, Young AB (1995) NMDA receptor subunit mRNA expression by projection neurons and interneurons in rat striatum. J Neurosci 15:5297-5307.

Laube B, Kuryatov A, Kuhse J, Betz H (1993) Glycine-glutamate interactions at the NMDA receptor: role of cysteine residues. FEBS Lett 335:331-334.

Laurie DJ, Seeburg PH (1994) Regional and developmental heterogeneity in splicing of the rat brain NMDAR1 mRNA. J Neurosci 14:3180-3194.

Laurie DJ, Putzke J, Zieglgansberger W, Seeburg PH, Tolle TR (1995) The distribution of splice variants of the NMDAR1 subunit mRNA in adult rat brain. Mol Brain Res 32:94-108.

Leonard AS, Hell JW (1997) Cyclic AMP-dependent protein kinase and protein kinase $\mathrm{C}$ phosphorylate $N$-methyl-D-aspartate receptors at different sites. J Biol Chem 272:12107-12115.
Maler L, Wang D (1997) Second messengers and synaptic plasticity in the electrosensory lateral line lobe of an electric fish. Soc Neurosci Abstr 23:101.9.

Maler L, Sas E, Johnston S, Ellis W (1991) An atlas of the brain of the electric fish Apteronotus leptorhynchus. J Chem Neuroanat 4:1-38.

Meguro H, Mori H, Araki K, Kushiya E, Kutsuwada T, Yamazaki M, Kumanishi T, Arakawa M, Sakimura K, Mishina M (1992) Functional characterization of a heteromeric NMDA receptor channel expressed from cloned cDNAs. Nature 357:70-74.

Monyer H, Sprengel R, Schoepfer R, Herb A, Higuchi M, Lorneli H, Burnashev N, Sakmann B, Seeburg PH (1992) Heteromeric NMDA receptors: molecular and functional distinction of subtypes. Science 256:1217-1221.

Monyer H, Burnashev N, Laurie DJ, Sakmann B, Seeburg PH (1994) Developmental and regional expression in the rat brain and functional properties of four NMDA receptors. Neuron 12:529-540.

Moriyoshi K, Masu M, Ishii T, Shigemoto R, Mizuno N, Nakanishi S (1991) Molecular cloning and characterization of the rat NMDA receptor. Nature 354:31-37.

Nakanishi N, Axel R, Shneider NA (1992) Alternative splicing generates functionally distinct $N$-methyl-D-aspartate receptors. Proc Natl Acad Sci USA 89:8552-8556.

O'Hara PJ, Sheppard PO, Thogersen H, Venizia D, Haldeman BA, McGrane V, Houamed KM, Thomsen C, Gilbert TL, Mulvihill ER (1993) The ligand-binding domain in metabotropic glutamate receptors is related to bacterial periplasmic binding proteins. Neuron $11: 41-52$.

Paoletti P, Neyton J, Ascher P (1995) Glycine-independent and subunitspecific potentiation of NMDA responses by extracellular $\mathrm{Mg}^{2+}$. Neuron 15:1109-1120.

Paupard MC, Friedman LK, Zukin RS (1997) Developmental regulation and cell-specific expression of $N$-methyl-D-aspartate receptor splice variants in rat hippocampus. Neuroscience 79:399-409.

Petralia RS, Yokotani N, Wenthold RJ (1994) Light and electron microscope distribution of the NMDA receptor subunit NMDAR1 in the rat nervous system using a selective anti-peptide antibody. J Neurosci 14:667-696.

Planells-Cases R, Sun W, Ferrer-Montiel AV, Montal M (1993) Molecular cloning, functional expression, and pharmacological characterization of an $N$-methyl-D-aspartate receptor subunit from human brain. Proc Natl Acad Sci USA 90:5057-5061.

Sheng M, Kim E (1996) Ion channel associated proteins. Curr Opin Neurobiol 6:602-608.

Sigel E, Baur R, Malherbe P (1994) Protein kinase C transiently activated heteromeric $N$-methyl-D-aspartate receptor channels independent of the phosphorylatable C-terminal splice domain and of consensus phosphorylation sites. J Biol Chem 269:8204-8208.

Simmons DM, Arriza JL, Swanson LW (1989) A complete protocol for in situ hybridization of mRNAs in brain and other tissues with radiolabeled single-stranded RNA probes. J Histotechnol 12:169-181.

Soloviev MM, Brierley MJ, Shao ZY, Mellor IR, Volkova TM, Kamboj R, Ishimaru H, Sudan H, Harris J, Foldes RL, Grishin EV, Usherwood PNR, Barnard EA (1996) Functional expression of a recombinant unitary glutamate receptor from Xenopus, which contains $N$-methyl-Daspartate (NMDA) and non-NMDA receptor subunits. J Biol Chem 271:32572-32579.

Standaert DG, Testa CM, Young AB, Penney Jr JB (1994) Organization of $N$-methyl-D-aspartate glutamate receptor gene expression in the basal ganglia of the rat. J Comp Neurol 343:1-16.

Standaert DG, Landwehrmeyer GB, Kerner JA, Penney JB, Young AB (1996) Expression of NMDAR2D glutamate receptor subunit mRNA in neurochemically identified interneurons in the rat neostriatum, neocortex, and hippocampus. Mol Brain Res 42:89-102.

Stern-Bach Y, Bettler B, Hartley M, Sheppard PO, O'Hara PJ, Heinemann SF (1994) Agonist selectivity of glutamate receptors is specified by two domains structurally related to bacterial amino acid-binding proteins. Neuron 13:1345-1357.

Sugihara H, Moriyoshi K, Ishii T, Masu M, Nakanishi S (1992) Structures and properties of 7 isoforms of the NMDA receptor generated by alternative splicing. Biochem Biophys Res Commun 185:826-832.

Tingley WG, Roche KW, Thompson AK, Huganir RL (1993) Regulation of NMDA receptor phosphorylation by alternative splicing of the C-terminal domain. Nature 364:70-73.

Tingley WG, Ehlers MD, Kameyama K, Doherty C, Ptak JB, Riley CT, Huganir RL (1997) Characterization of protein kinase A and protein 
kinase C phosphorylation of the $N$-methyl-D-aspartate receptor NR1 subunit using phosphorylation site-specific antibodies. J Biol Chem 272:5157-5166.

Tong G, Shepherd D, Jahr CE (1995) Synaptic desensitization of NMDA receptors by calcineurin. Science 267:1510-1512.

Traynelis SF, Hartley M, Heinemann SF (1995) Control of proton sensitivity of the NMDA receptor by RNA splicing and polyamines. Science 268:873-876.

Wafford KA, Kathoria M, Bain CJ, Marshall G, Le Bourdelles B, Kemp JA, Whiting PJ (1995) Identification of amino acids in the $N$-methylD-aspartate receptor NR1 subunit that contribute to the glycine binding site. Mol Pharmacol 47:374-380.

Wang D, Maler L (1994) The immunocytochemical localization of glutamate in the electrosensory system of the gymnotiform fish, Apteronotus leptorhynchus. Brain Res 653:215-222.

Wilson AC, Carlson SS, White TJ (1977) Biochemical evolution. Annu Rev Biochem 46:573-639.

Wong CJ (1997) Afferent and efferent connections of the diencephalic prepacemaker nucleus in the weakly electric fish, Eigenmannia virescens: interactions between the electromotor system and the neuroendocrine axis. J Comp Neurol 383:18-41.
Wyszynski M, Lin J, Rao A, Nigh E, Beggs AH, Craig AM, Sheng M (1997) Competitive binding of alpha-actinin and calmodulin to the NMDA receptor. Nature 385:439-442.

Yamazaki M, Mori H, Araki K, Mori KJ, Mishina M (1992) Cloning, expression, and modulation of a mouse NMDA receptor subunit. FEBS Lett 300:39-45.

Zhang L, Zheng X, Paupard MC, Wang AP, Santchi L, Friedman LK, Zukin RS, Bennett MV (1994) Spermine potentiation of recombinant $N$-methyl-D-aspartate receptors is affected by subunit composition. Proc Natl Acad Sci USA 91:10883-10887.

Zheng X, Zhang L, Durand GM, Bennett MV, Zukin RS (1994) Mutagenesis rescues spermine and $\mathrm{Zn}^{2+}$ potentiation of recombinant NMDA receptors. Neuron 12:811-818.

Zheng X, Zhang L, Wang AP, Bennett MVL, Zukin RS (1997) $\mathrm{Ca}^{2+}$ influx amplifies protein kinase $C$ potentiation of recombinant NMDA receptors. J Neurosci 17:8676-8686.

Zimmer M, Fink TM, Franke Y, Lichter P, Spiess J (1995) Cloning and structure of the gene encoding the human $N$-methyl-D-aspartate receptor (NMDAR1). Gene 159:219-223.

Zukin RS, Bennett MV (1995) Alternatively spliced isoforms of the NMDAR1 receptor subunit. Trends Neurosci 18:306-313. 